\title{
Integral or Irrelevant: What Makes a Desirable College Intern?
}

\author{
Shannon McQueen, Clinton Jenkins, and Susan Wiley
}

February 2020

What constitutes a 'quality' college intern? Interning is an integral part of the student experience at George Washington University. It enables students to develop job skills, build confidence, and apply classroom knowledge to the work environment. Although the benefits of interning are well known, we know less about the qualities and skills that make a desirable intern. In this research, we examine what internship sponsors desire in a George Washington University political science student intern. We analyze quantitative sponsor evaluations of the student intern's performance looking at dependability, work ethic, attendance, usefulness to the organization, and level of initiative. We also apply qualitative techniques to analyze sponsors' comments regarding tasks the intern was assigned, the value of the internship, and the positive and negative aspects of the intern. The analysis is done by the intern's gender and by the organizational category. Through this research, we offer a greater understanding of the role of internships to undergraduate education, as well as provide insight into interns' performance while completing their internships. 


\section{Introduction}

Interning is quickly becoming an integral part of the student experience across universities. In 2019, the National Association of Colleges and Employers (NACE) found, "graduating seniors who applied for a full-time job and participated in an internship received 1.17 job offers; while those who did not intern received 16\% fewer job offers" (NACE 2019). Internships are incredibly valuable for students and can have long lasting post-graduation effects. However, we know substantively less about what companies and organizations that hire interns look for in their ideal college intern. This information is crucial to the success of our students, and has not been examined through an academic lens.

This paper explores the understudied side of internships, investigating what makes a great college intern from the perspective of the internship supervisor. Using data from political science majors at George Washington University (GWU), we surveyed nearly 400 internship supervisors from 2013 to 2018 and use quantitative and qualitative assessments to determine what internship supervisors look for in an ideal intern.

We find no difference in intern evaluations between genders or different types of internship opportunities. We find internships tend to require substantial amounts of writing, communication, and research by interns. Additionally, students were critiqued for lack of attention to detail and lack of initiative. The ideal college intern tends to have a strong team associated attitude, quality work produced, and a level of initiative. These results have implications for how political science faculty design curriculum and what skills are emphasized in preparing students for future careers.

\section{What We Know about College Internships}


Internships refer to any work or service experiences under the monitoring of a supervisor, relating to the career goals of the student (NACE 2018). Much of the internship literature concerns what benefits internships bring to students in school, in the job market, and civic spheres. While in school, internships are a valuable tool to apply classroom concepts to realworld phenomena (Parilla and Hesse 1998; Allen, Parker, and DeLorenzo 2012). Completing an internship is associated with tangible academic gains, such as an increased grade point average (Routon and Walker 2015, 2018; Healy and Mourton 1987; Knouse et al. 1999) and skill development, including time management, communication skills, self-discipline, teamwork, problem-solving, and initiative (Dennis, 1996: Healy \& Mourton 1987; Kane, Healy, \&Henson 1992; Taylor, 1988; Routon and Walker 2018).

Psychologically, internships can impact how students view themselves, their possibilities, and their entire college experience. Internships have a positive effect on student's desire to attend graduate school, own a business, attain personal financial wealth, and work in administrative positions (Routon and Walker 2015, 2018). Students also reported more satisfaction with their achievements (Adams 2018) and their college experience as a whole (Routon and Walker 2018).

Considering the job market, internships are seen as an important way to gain work experience (Schomburg and Teichler 2011; Silva et al. 2016). For students, internships can help narrow down career choices and decrease the difficulties of transitioning out of school and into the workforce (Hall, 1976: Kane et al., 1992; Kane er all 2993, Taylor 1988). Specifically, holding an internship is associated with a lower risk of unemployment during the first year after graduation (Margaryan et a;1 2019; Passaretta and Triventi 2015; Gellner 2012; Weiss, Klein, and Grauenhorst 2014; Saniter and Siedler 2014, but see Knouse et al. 1999, who notes that the internship advantage of early job security neutralizes six months post-graduation). Some scholars 
even claim internships are associated with higher pay rates (Nunley et all 2016). Perhaps less exciting to students than pay raises, political science internships are specifically associated with the development of key civic skills, such as political participation (Eyler and Halteman 2003), internal political efficacy, and trust (Mariani and Klinkner 2009).

As the majority of the literature concerns the value of internships for students, we know little about what makes a desirable college intern. There is a common conception that that "the intern makes the program" (Hedlund 1973), but we do not know what personal attributes or skills intern supervisors value. There is anecdotal evidence that those who hire political science interns may "look for prior political involvement, the ability to get along well with others, at least a modest intellectual ability and self-assurance" (Hedlund 1973). Others note qualities like emotional stability, maturity, tact, and energy, and sense of political curiosity (Hedlund 1973). However, to our knowledge, no systematic assessment of desirable internship traits has yet been completed, making this paper a key resource.

\section{The Internship Process at George Washington University}

The Political Science Department is six blocks from the White House, four metro stops from the U.S. Capitol, and walking distance to the K Street corridor with numerous law firms, NGOs and lobbying firms. The Princeton Review ranks GWU as number one for internships and servicelearning opportunities, likely in part due to this unique location (Princeton Review 2016).

PSC 2987, Internship in Political Behavior, the department credit internship program, is offered fall, spring, and summer semesters. To register, a student must be a declared Political Science major with at least junior standing, have a confirmed internship, and have completed a minimum of three Introductory Political Science courses. The Political Science Department 
maintains a list of available internships, as does Career Services. Often the department has more requests for interns than we have students to fill the internships. Each student registering for PSC 2987 must complete a learning contract signed by the internship sponsor outlining the nature of the internship, the substantive work to be completed, the student's learning objectives, and a proposed paper topic. The paper due at the end of the semester is expected to enhance the student's capability on the job and should be based on some issue or problem that concerns the agency or office in which the student works. Students are expected to meet with or email the Director of Undergraduate Studies every three or four weeks, briefly stating what they have been doing in the internship and if they have any problems or concerns. The internship paper is due the last day of classes. Internship sponsors are also asked to submit a student evaluation.

PSC 2987 is variable, 1, 2, or 3, credits: For one credit the student must intern a minimum of 8 hours per week and write a 10-page paper. For two credits a student must intern a minimum of 10 hours per week and write a 12-page paper. For three credits a student must intern a minimum of 15 hours per week and write a 15-page paper. The class is graded as a Pass/Fail. Up to three credits of PSC 2987 may be earned towards the political science major. Students may take PSC 2987 again, however, the additional credits count only as elective credit towards the degree and not towards the Political Science major.

The Political Science department and GWU strive to make the internship class as accessible as possible. Credit may be earned for a paid or unpaid internship, and the GW Career Services Center has funds available for students who are foregoing Federal Work-Study in order to intern. There are also transportation funds available to students who are interning. Because there is no financial aid available in the summer session, the Director of Undergraduate Studies negotiated an agreement with the University Provost to permit students who intern during the 
summer to receive credit in the fall. During an academic year between 120 and 130 majors register for PSC Internship credit, or around 20\% of declared Political Science majors. Many other majors intern, but do not register for credit. Over the last academic year, the percentage of students registered for internship credit in Political Science by internship location was:

31\% Capitol Hill

5\% White House

15\% Government Agencies

$14 \%$ Non-Governmental Organizations

24\% Lobbying Campaigns, and Polling Firms

6\% Think Tanks and Research Organizations

5\% Other Locations including Media, Law Firms, and Embassies

\section{Data and Methods}

The data set is composed of slightly over 370 internship evaluation forms collected during Fall and Spring semesters between 2013 and 2018. The forms are requested from the internship supervisor at the end of each semester, and distributed via emails. These forms include both qualitative and quantitative measures of intern performance. About $76 \%$ of internships occurred in the Spring semesters. The quantitative data has been analyzed using Stata, while the qualitative data has been analyzed using Atlas.ti. ${ }^{1}$ There was very little variation in the results

\footnotetext{
${ }^{1}$ Atlas.ti is a qualititive analysis software suite developed to allow researchers to conduct a variety of types of qualitative data analysis on data in a variety of formats ranging from audio clips, text documents, images, social media data, and more. More information can be found at: https://atlasti.com/product/what-is-atlas-ti/
} 
between the location where students work, or between students' gender, and thus we present the results aggregated for all evaluations. An analysis broken down by internship category can be found in the appendix.

\section{Results}

\subsection{Location and Time}

Students interned at a range of organizations, such as political campaigns, law firms, international embassies, and well-known think tanks. Overall, we broadly grouped location into five categories depicted in Figure 1, nonprofit or advocacy organizations, think tanks or research organizations, international governments, the United States government, and businesses or corporations.

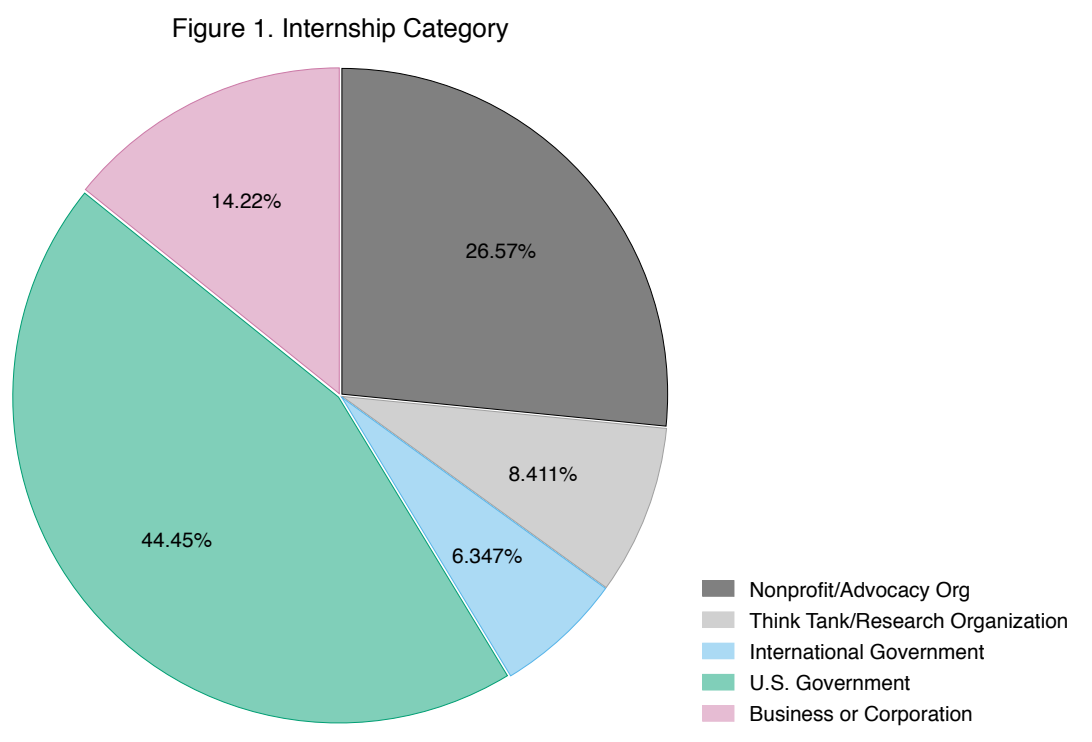

Slightly under half of all internships involved the United States government, which includes generally thought of "hill internships" in representatives' offices, as well as more unconventional placements, such as serving in the Office of the First Lady or for the Committee on Homeland 
Security. About $25 \%$ of internships occur at nonprofit or advocacy organizations. These include partisan organizations (such as the Republican Governors Association) and advocacy groups, such as Planned Parenthood, the Human Rights Campaign, or Refugee International. Around $14 \%$ of internships occur at businesses or corporations such as law offices or media consulting groups. Fewer students intern in think tanks or international governing bodies. There are no significant differences between where men and women intern. ${ }^{2}$

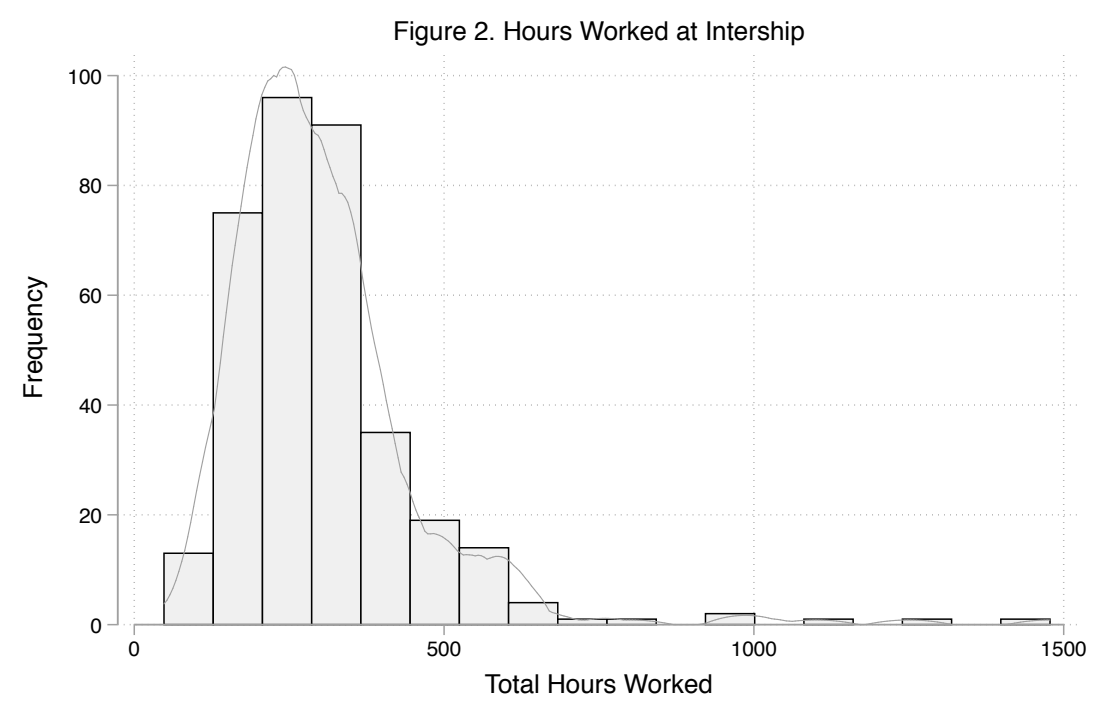

As demonstrated in Figure 2, there is considerable variation in the number of hours a student spends interning. In fact, the standard deviation is 159 hours. The majority of students interned under 500 hours, with an average of 300 hours. Those students working over 500 hours may have interned for longer than the length of a semester or interned for an extremely demanding organization, such as the White House Office of Public Engagement, where one student worked 1,100 hours.

\subsection{Overall Performance}

${ }^{2}$ See Appendix for results. 
The quantitative assessment addressed the students' performance, with respect to dependability, work ethic, attendance, and usefulness, working effectively with others, quality and quantity of work produced, and level of initiative. These were assessed on a scale of 1 (poor) to 5 (excellent). As Figure 3 demonstrates, most students received 5's or 4's on these assessments, indicating very high levels of satisfaction. However, level of initiative had a slightly lower average than the other questions and the biggest range in ratings. This is mirrored in the qualitative results as well, as many supervisors requested students take more initiative on projects.

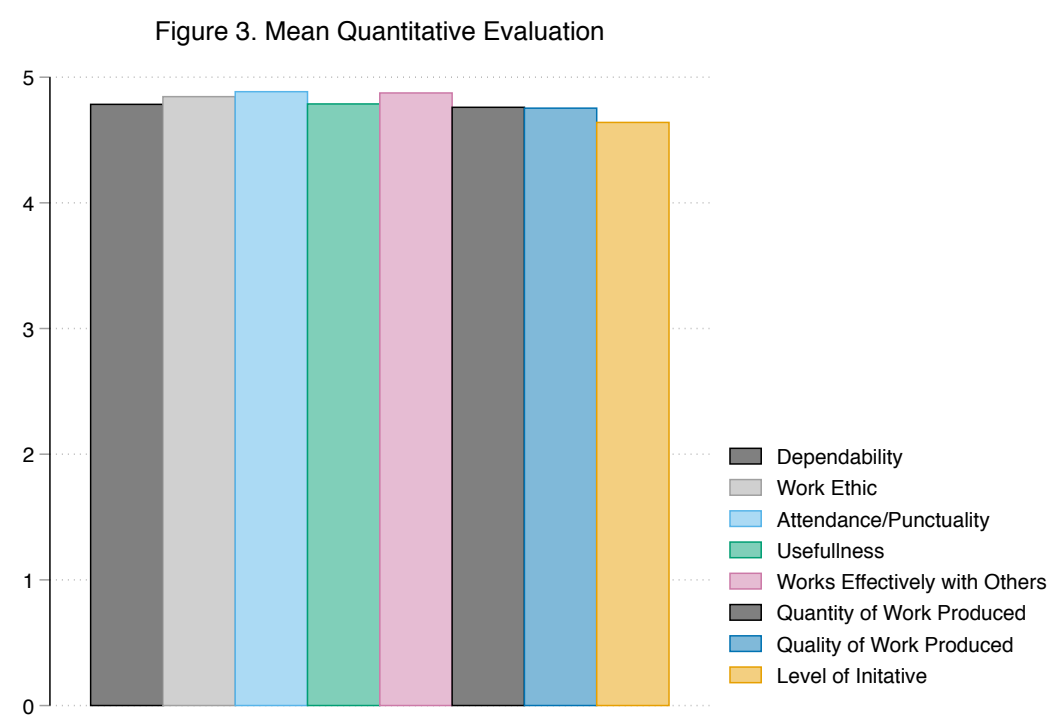

All supervisors agreed that the internship experience was a good learning experience for the student, the student should earn credit, and the student's performance was satisfactory. Additionally, all respondents were interested in having another GWU student intern for them. The questions with the most variation in responses asks if supervisors have shared their evaluation with the students. The respondents are evenly split, as $49 \%$ of respondents have not shared the evaluation, while 50\% have shared the evaluation. There are no gender differences between those who have shared and those who have not shared. 


\subsection{Skill Development}

In addition to the quantitative assessment, Interview supervisors answered multiple openended questions. First, respondents described the intern's work completed during the internship. Many used terms like "research" and "project," indicating the heavy research component many internships had. Additionally, words like "team," "us," "staff," and "helped" underscore the importance of interpersonal and teamwork skills within the internship.

Ultimately there were five main skills common across internships. These include writing and communication, event planning, management skills, research and analytic skills, and service. Slightly more than $40 \%$ of students had writing or communications components. This group includes a wide range of projects, all of which concern summarizing and sharing information, such as giving presentations, writing policy, legal, and research briefs, crafting a proposal for a new podcast, developing advocacy documents. One student interning at a consulting firm even developed a new business plan for the firm, "including a marketing plan, budget forecast, and people plan."

Table 1: Internship Activity

\begin{tabular}{cc}
\hline \hline & Percentage \\
\hline Communication and Writing & $43.4 \%$ \\
Research and Analytics & $33.6 \%$ \\
Service & $8.8 \%$ \\
Event Planning & $7.7 \%$ \\
Management & $6.5 \%$ \\
\hline
\end{tabular}

Next, the most common activity includes research and data skills mentioned in around $30 \%$ of all activity comments. This skill may involve compiling, researching, or analytic skills 
concerning a range of topics. One student analyzed congressional and think tank hearings, while another was a "key researcher for new business proposals." The research includes client-focused work from consulting firms and topic-centered research from think tanks and nonprofit or advocacy planning.

Event planning, management skills, and service-based skills are all relatively similar in their frequency, as they are mentioned in under $10 \%$ of all comments. Event planning often referred to assisting with preparations for large events, such as one student who organized and marshaled the crowd at a climate march, or another student who organized "Press Breakfasts" on Capitol Hill. One student was so successful in helping their organization plan a forum in Brussels that the organization brought them to Brussels to assist with the event. Management refers to any time students are leading a team or monitoring others, such as one student who managed recruit, organize, and train hundreds of volunteers for a congressional race, or another who trained new interns and volunteers on how to contact voters. Finally, service refers to any work done to connect or appease clients. Most of these comments come from hill intern supervisors, whose intern engaged in consistent services, such as capitol tours or handling constituent concerns.

Students often engaged in more than one activity in their internship. Very often, those who had a research component were required to share or summarize findings. For example, one student had to prepare updates for Facebook leadership on election integrity work, using both research and communication skills. Another followed several conferences on think tanks, and ultimately wrote a report of their findings.

\subsection{The Internship's Value}


Supervisors were asked what value they saw in the internship for the students. Around $25 \%$ of respondents mentioned the value of the intern working in a unique experience or environment. For example, one student was able to experience daily press meetings, which "exposed him to the deeper communication strategy of a [Capitol] Hill Press team." Others noted the environment allowed for developing new skills, meeting new people, or learning about a particular topic. Around $17 \%$ of comments noted how this experience supplements classroom learning, providing "real-life" or "hands-on" experience. One respondent from a consulting firm wrote, "there is no substitute for seeing how the sausage is made, and you can't get that in a classroom." Another noted that the internship with a well-regarded think tank provides "hands-on experience with the policymaking process. Interns learn how to convene multiple stakeholders, organize and run strategy sessions and roundtable discussions, research, and analyze policy position."

Table 2: Internship Value

\begin{tabular}{cc}
\hline \hline & Percentage \\
\hline Nuanced or Detailed Experience & $25.1 \%$ \\
Knowledge Development & $22.5 \%$ \\
"Real Life" Experience & $17.2 \%$ \\
Skill Development & $14.6 \%$ \\
Effort or Time Spent & $9.6 \%$ \\
"Useful for Future" & $8.3 \%$ \\
Importance of Work for Organization & $2.7 \%$ \\
\hline
\end{tabular}

Adjacently, many simply noted the knowledge or skills gained through the internship, including valuable professionalization skills. Around $8 \%$ of respondents said the experience would be useful for the intern's future. For example, one supervisor noted how their intern "was able to witness firsthand how a nonprofit work[SIC] and was able to gain professional experience that will be valuable throughout her life." About $9.6 \%$ of respondents noted that the time and effort the intern invested during the internship. Beyond the value for the intern, slightly 
under 3\% of comments noted how the work was important for the organization, such as a local police department, which noted that the intern's "service increased the efficiency for our daily operations. I feel the contribution added value to our office."

\subsection{Room for Improvement}

We prompted Internship supervisors to note how the intern could improve their work. Overall, there were nine main categories of responses. All these responses are skill-based concerns, which including both individual and interpersonal management. Writing and communication criticisms is the largest category for improvement. Many comments suggested honing writing skills, and looking for opportunities to improve their craft. Other communication comments noted something more interpersonal, such as a lack of ability to communicate, listen with supervisors, or share progress. For example, one respondent suggested the intern "listen carefully when work instructions were being set out," and another noted how the intern missed communicating with staff members or networking.

Table 3: Improvements for Interns

\begin{tabular}{cc}
\hline \hline & Percentage \\
\hline Writing and Communication & $21.6 \%$ \\
Initiative Taking & $18.7 \%$ \\
Attention to Detail & $13.7 \%$ \\
Deepen Knowledge & $11.6 \%$ \\
More Confidence & $8.8 \%$ \\
Time Management and Organization & $7 \%$ \\
Interpersonal Skills & $6.3 \%$ \\
Engagement & $4.2 \%$ \\
Self Management & $4.9 \%$ \\
Not Responding to Correction & $1.8 \%$ \\
Speed & $1.4 \%$ \\
\hline
\end{tabular}


There were also interpersonal or emotive criticisms, such as a lack of engagement and a desire for more confidence and more initiative. A lack of initiative is the largest percentage of this group, as almost $20 \%$ of comments mentioned a desire for the intern to take the initiative. These findings are not unexpected, as for many college students' this experience may be their first work-related experience. They likely feel nervous or vulnerable in this new setting, making them less likely to express confidence or to take risks and demonstrate initiative by asking for more work.

\subsection{A Positive Note}

Although there was room for improvement, around $20 \%$ of all comments were positive, regardless of what type of organization one worked for, or the gender of the intern (See Appendix). Internship supervisors often used words like "great," "pleasure," "fantastic," "excellent," "good," and "quality." Some respondents were so impressed by the work of the intern, that respondents extended internships, offered jobs, or event brought along an intern to Brussels to help with a foreign forum. As an example, one comment notes the intern "is a force of nature! I kept having to remind myself she is a full-time student at my beloved alma mater, in addition to interning. Another supervisor noted that the intern "has been a great addition to our policy staff and has contributed in many ways. He has a can-do attitude, and we have invited him to stay on as a paid intern through the summer. He will help to staff our annual conference and trade show in early June."

Interestingly, many of the positive comments demonstrate a strong level of engagement and initiative, and strong quality produced. For example, one respondent noted they would "hire the student here in a heartbeat! He was a pleasure to work with and showed a lot of initiative." 
Another respondent specifically noted that “the student doesn't just complete tasks, he goes above, and beyond every time he delivers an assignment. He has completely restructured our team site as asked, while at the same time contributing fresh ideas and methods on his own for how to improve it. I can always rely on the quality of his work." This combination of initiative, positive team attitude, and quality of work stuck out to make standard interns become star interns.

\section{Conclusion}

This paper provides an overview of the internship experience from an often-overlooked component, the internship supervisor. The survey results reveal that interns at George Washington University are doing an impressive amount of work. There is a significant focus on writing/communication and research-based skills. Additionally, many internship supervisors see being in this new environment a helpful supplement to classroom learning. When considering what makes a standout intern, we see a trend of quality work, alongside a team-oriented spirit and initiative within the work. This is evident both in the qualities interns were praised for, as well as the things about which intern supervisors noted interns could improve upon. Similar to other's (Knouse et al. 1999), we find no gender differences in evaluations.

These findings are important for students, as they have a vested interest in knowing what skills and qualities supervisors desire in internship and job experiences. This knowledge may help students transition into the workforce and successfully start the beginnings of their careers. Additionally, this information can be informative for political science faculty concerned with teaching skills that apply to political science students in the workforce. Understanding what 
skills and qualities are in demand for political science majors can inform how political science curriculum is developed.

The results indicate that a greater focus three critical skills may assist students transitioning into the workforce. First, communication - both of content and interpersonal communication - is vital to students transitioning to the workforce. Including more in-class presentations of material, providing space for more interactions with peers in class, and allowing for more structured meetings with professors to discuss project status can assist in strengthening communication skills with teams and supervisors. Second, many internship supervisors noted the need for attention to detail. Inviting students into the editing process by assigning longer-term projects with draft milestones can enrich this editing skill. Finally, the most desired trait for interns was to take greater inactive. Although teaching initiative is challenging, political science faculty can design a curriculum that can empower students to take greater initiative in their research projects, allowing for the development of management skills and confidence. Incorporating more team-oriented self-designed research projects that mimic "real life" analysis can help students prepare for the type of work they may do after graduation.

This project should be extended, as there are generalizability concerns with only looking at George Washington University Students. Those students at the nation's capital have a unique experience and privilege to interning compared to students in other locations. Furthermore, George Washington University Political Science Department provides structural and academic support for these students. This support is not always available in all universities. Externally, the work available and desire for political science students to intern is particularly present in the Washington D.C. area. Students may be invited to engage in data analytics or policy-related work at higher rates or have unique experiences that can only occur on Capitol Hill. A full 
analysis of the internship experience in other areas of the country would be valuable to assess what skills employees desire from Political Science graduates. 


\section{Works Cited}

Allen, Mahalley D., Sally A. Parker, and Teodora C. DeLorenzo. "Civic Engagement in the Community: Undergraduate Clinical Legal Education." Journal of Political Science Education 8, no. 1 (2012): 35-49.

Bennion, Elizabeth A., and Xander E. Laughlin. "Best Practices in Civic Education: Lessons from the Journal of Political Science Education." Journal of Political Science Education 14, no. 3 (2018): 287-330.

Bernstein, Jeffrey L., and Deborah S. Meizlish. "Becoming Congress: A longitudinal study of the civic engagement implications of a classroom simulation." Simulation \& Gaming34, no. 2 (2003): 198-219.

Dennis, A. "The benefits of using college interns in a firm." Journal of Accountancy 181 (1996): 889-892.

Geel, Regula, and Uschi Backes-Gellner. "Earning while learning: When and how student employment is beneficial." Labour 26, no. 3 (2012): 313-340.

Hall, Douglas T. "Careers in organizations. Santa Monica." California: Goodyear (1976).

Healy, C. C., \& Mourton, D. L. (1987). The relationship of career exploration, college jobs, and grade point average. Journal of College Student Personnel.

Hedlund, Ronald D. "Internship Evaluation: A Review and Proposal." Public Service Internship News (1973): 5-8.

Hirschfield, Robert S., and Norman M. Adler. "Internships in politics: the CUNY experience." PS: Political Science \& Politics6, no. 1 (1973): 13-18.

Kane, S. T., Healy, C. C., \& Henson. J. (1992).College students and their part- time jobs: Job congruency, satisfaction, and quality. Journal of Employment Counseling, 29, 138-144.

Koc, Edwin, Joshua Kahn, Andrea Koncz, Angelena Salvadage, and Anna Longenberger. "2019 Internship \& Co-Op Survey Report Executive Summary."

https://www.naceweb.org/uploadedfiles/files/2019/publication/executive-summary/2019-naceinternship-and-co-op-survey-executive-summary.pdf National Association of Colleges and Employers, May 2019.

Knouse, Stephen B., and Gwen Fontenot. "Benefits of the business college internship: A research review." Journal of Employment Counseling 45, no. 2 (2008): 61-66.

Knouse, Stephen B., John R. Tanner, and Elizabeth W. Harris. "The relation of college internships, college performance, and subsequent job opportunity." Journal of employment Counseling 36, no. 1 (1999): 35-43. 
Laughlin. 2016. "Using Internships to Promote Student Learninf and Engagement: An Annotated Bibliography." The Political Science Educator 20 (1):8-10.

Margaryan, Shushanik, Nils Saniter, Mathias Schumann, and Thomas Siedler. "Do Internships Pay Off? The Effects of Student Internships on Earnings." (2019).

Mariani, Mack, and Philip Klinkner. "The effect of a campaign internship on political efficacy and trust." Journal of Political Science Education 5, no. 4 (2009): 275-293.

Nunley, John M., Adam Pugh, Nicholas Romero, and R. Alan Seals Jr. "College major, internship experience, and employment opportunities: Estimates from a résumé audit." Labour Economics 38 (2016): 37-46.

Parilla, Peter F., and Garry W. Hesser. "Internships and the sociological perspective: Applying principles of experiential learning." Teaching Sociology (1998): 310-329.

Passaretta, Giampiero, and Moris Triventi. "Work experience during higher education and postgraduation occupational outcomes: A comparative study on four European countries." International Journal of Comparative Sociology 56, no. 3-4 (2015): 232-253.

Routon, P. Wesley, and Jay K. Walker. "A smart break? College tenure interruption and graduating student outcomes." Education Finance and Policy 10, no. 2 (2015): 244-276.

Routon, P., and Jay K. Walker. "College Internships, Tenure Gaps, and Student Outcomes: A Multiple-Treatment Matching Approach." (2018).

Saniter, Nils, and Thomas Siedler. "Door opener or waste of time? The effects of student internships on labor market outcomes." (2014).

Schomburg, Harald, and Ulrich Teichler. Employability and mobility of bachelor graduates in Europe. New York: Springer, 2011.

Silva, Patrícia, Betina Lopes, Marco Costa, Dina Seabra, Ana I. Melo, Elisabeth Brito, and Gonçalo Paiva Dias. "Stairway to employment? Internships in higher education." Higher Education 72, no. 6 (2016): 703-721.

Taylor, M. Susan. "Effects of college internships on individual participants." Journal of Applied Psychology 73, no. 3 (1988): 393.

Weiss, Felix, Markus Klein, and Thomas Grauenhorst. "The effects of work experience during higher education on labour market entry: learning by doing or an entry ticket?." Work, employment and society 28, no. 5 (2014): 788-807. 


\section{Appendix for 'Integral or Irrelevant: What Makes a Desirable College Intern?'}

By Shannon McQueen, Clinton Jenkins, and Susan Wiley

\section{A1. Location and Time}

Table 1. Internship Category by Gender.

\section{A2. Overall Performance}

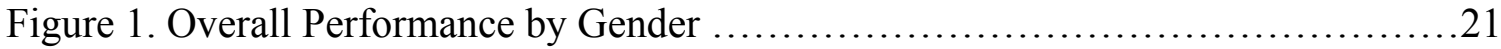

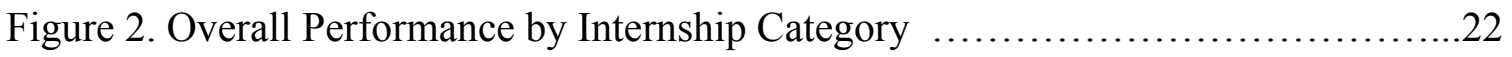

\section{A3. Skill Development}

Table 3. Skill Development by Gender ..........................................22

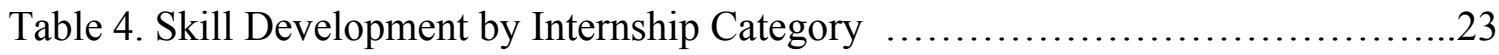

\section{A4. The Internship's Value}

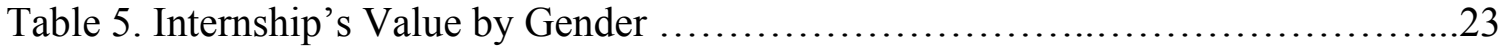

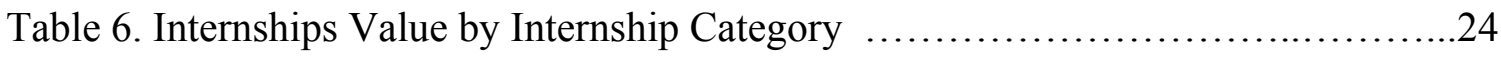

\section{A5. Room for Improvement}

Table 7. Critiques by Gender .................................................24

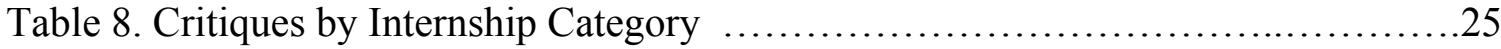

A6. A Positive Note

Table 9. Positive Comments by Gender .........................................25

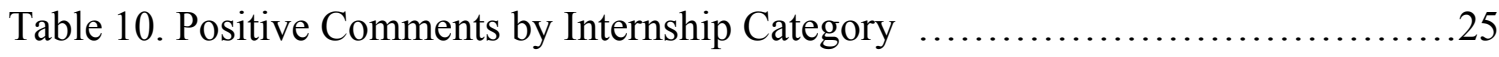

A7. Copy of Internship Evaluation Instrument ..........................26-27 


\section{A1. Location and Time}

Although slightly more males than females have utilized the internship program, there does not appear to be a substantial difference across categories of interning. The only exception is evident in those interning with the US government, where there is a gap is larger than 20 points between female and male students.

Table 1: Internship Category By Gender

\begin{tabular}{ccccccc}
\hline \hline & Nonprofit & Think Tank & International Govt. & U.S. Govt & Business & Total \\
\hline Female & $45.9 \%$ & $43.7 \%$ & $48 \%$ & $37.5 \%$ & $44.3 \%$ & $41.9 \%$ \\
Male & $54.1 \%$ & $56.3 \%$ & $52 \%$ & $62.5 \%$ & $55.7 \%$ & $58.1 \%$ \\
\hline
\end{tabular}

\section{A2. Overall Performance}

The analysis of performance between males and female is very similar. The only category that revels a discernable difference is attendance, where female students have a slightly higher rating than their male counterparts. There were also comparably high ratings in the student's skills, regardless of location of the internship.

Figure 1. Mean Quantitative Evaluations by Gender

Female

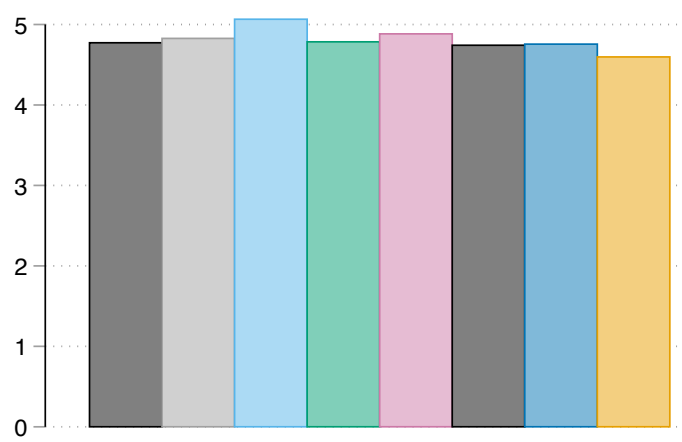

Male

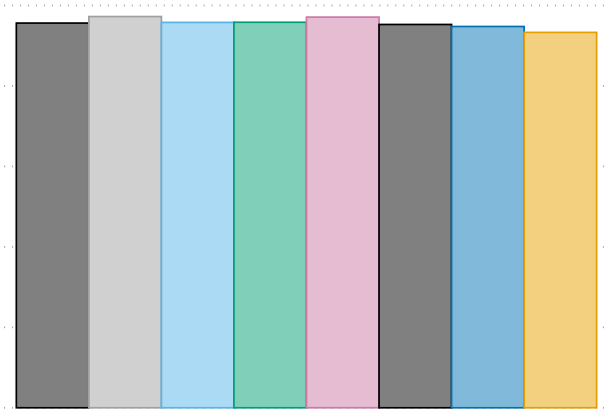

Dependability

Work Ethic

Attendance

Usefulness

Working Effectively with Others

Quality of Work

Quantity of Work

Level of Initative 


\section{Mean Quantitative Evaluation by Organization}

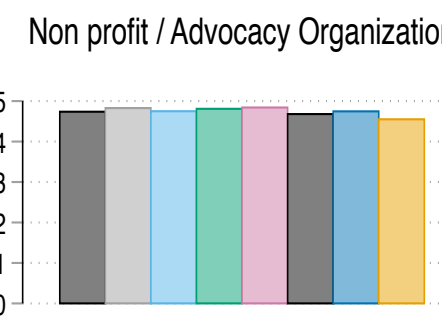

U.S. Government

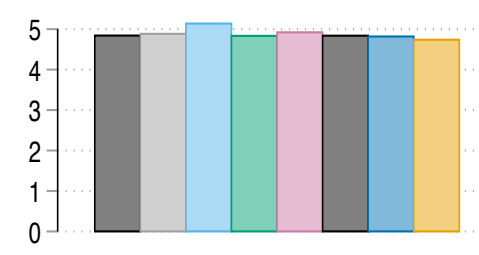

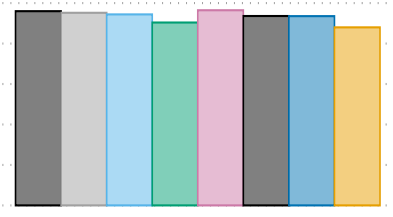

Business / Corporation

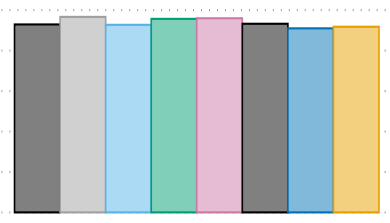

International Government

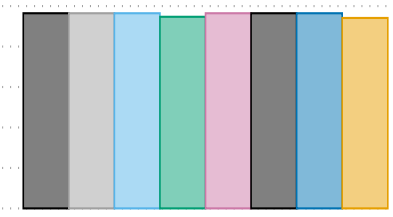
Dependability
Work Ethic
Attendance
Usefulness
Working effectively with Others
Quality of Work
Quantity of Work
Level of Initative

\section{A3. Skill Development}

There is fairly comparable internship activity between both males and females in Table 2 . The higher service rates likely reflect more males interning with the U.S. Government. In Table 3, comparing internship activities across location indicates some expected patterns. For example, think tanks mention communication and writing more, while the U.S. government mention service activities in reference to constituent assistance. However, research and analytic, as well as communication and writing skills are consistently mentioned frequently regardless of location.

Table 2: Internship Activity by Gender

\begin{tabular}{ccc}
\hline \hline & Females & Males \\
\hline Communication and Writing & $43.5 \%$ & $44.3 \%$ \\
Event Planning & $9.5 \%$ & $6.6 \%$ \\
Management & $7.5 \%$ & $4.3 \%$ \\
Research and Analytics & $35 \%$ & $33.6 \%$ \\
Service & $5.5 \%$ & $11.2 \%$ \\
\hline Percent of Comments Referring to Activities & $16.6 \%$ & $17.9 \%$ \\
\hline
\end{tabular}


Table 3: Internship Activity by Location

\begin{tabular}{|c|c|c|c|c|c|}
\hline & Nonprofit & Think Tank & International Govt & U.S. Govt & Business \\
\hline Communication and Writing & $43.5 \%$ & $27 \%$ & $41.2 \%$ & $45 \%$ & $49.3 \%$ \\
\hline Event Planning & $13.8 \%$ & $2.7 \%$ & $11.8 \%$ & $5.8 \%$ & $4.3 \%$ \\
\hline Management & $6.5 \%$ & $10.8 \%$ & $0 \%$ & $5.4 \%$ & $5.8 \%$ \\
\hline Research and Analytics & $33.5 \%$ & $56.8 \%$ & $38.2 \%$ & $28.6 \%$ & $38.7 \%$ \\
\hline Service & $2.7 \%$ & $2.7 \%$ & $8.8 \%$ & $15.2 \%$ & $1.9 \%$ \\
\hline Percent of Comments Referring to Activities & $17.3 \%$ & $14.3 \%$ & $39.4 \%$ & $47.45 .3 \%$ & $14.6 \%$ \\
\hline
\end{tabular}

\section{A4. Internship Value}

When considering the Internship value in Table 4 across genders, there are consistent values across genders. When considering internship activity by location in Table 5, there are no discernable patterns across location.

Table 4: Internship Value by Gender

\begin{tabular}{ccc}
\hline \hline & Females & Males \\
\hline "Real Life" Experience & $12.2 \%$ & $20.7 \%$ \\
Detailed or Nuanced Experience & $28.8 \%$ & $21.9 \%$ \\
Effort or Time Spent & $7.7 \%$ & $10.97 \%$ \\
Importance of Work to Organization & $2.7 \%$ & $2.4 \%$ \\
Knowledge Development & $24.4 \%$ & $21.95 \%$ \\
Skill Development & $16.1 \%$ & $13.4 \%$ \\
"Useful for Future" & $7.7 \%$ & $8.53 \%$ \\
\hline Percent of Comments Referring to Internships Value & $42.3 \%$ & $57.8 \%$ \\
\hline
\end{tabular}


Table 5: Internship Value by Location

\begin{tabular}{cccccc}
\hline \hline & \multicolumn{5}{c}{ Nonprofit } \\
\hline & $20.5 \%$ & $25 \%$ & $0.4 \%$ & $16.6 \%$ & $11.3 \%$ \\
\hline "Real Life" Experience & $23 \%$ & $20.5 \%$ & $25 \%$ & $27.3 \%$ & $24.2 \%$ \\
Detailed or Nuanced Experience & $7.7 \%$ & $4.5 \%$ & $6 \%$ & $10.7 \%$ & $14.5 \%$ \\
Effort or Time Spent & $2.6 \%$ & $2.3 \%$ & $6 \%$ & $2.7 \%$ & $1.6 \%$ \\
Importance of Work for Organization & $27.5 \%$ & $22.7 \%$ & $18.8 \%$ & $20.9 \%$ & $22.6 \%$ \\
Knowledge Development & $12.8 \%$ & $9.1 \%$ & $37.5 \%$ & $13.8 \%$ & $17.7 \%$ \\
Skill Development & $5.9 \%$ & $15.9 \%$ & $6.3 \%$ & $8 \%$ & $8.1 \%$ \\
"Useful for Future" & $15.5 \%$ & $16.9 \%$ & $8.6 \%$ & $14.8 \%$ & $21.8 \%$ \\
\hline Percent of Comments Referring to Internship Value & $15 \%$ & & & &
\end{tabular}

\section{A5. Room for Improvement}

Table 6 indicates that most criticisms are fairly similar between categories. The only notable exception is interpersonal skills, as male students have double the criticisms in interpersonal skills compared to females. When comparing criticism across internship location, certain criticisms are more prevalent for specific locations, as they likely reflective of the activity more prevalent within the internship. However, there is a fairly consistent rate of criticisms across the categories, and some critiques have a greater presence regardless of category, such as taking initiative, and writing and communication.

Table 6: Criticisms by Gender

\begin{tabular}{ccc}
\hline \hline & Females & Males \\
\hline Attention to Detail & $12.6 \%$ & $14.7 \%$ \\
Deepen Knowledge & $12.7 \%$ & $10.7 \%$ \\
Engagement & $6.6 \%$ & $2 \%$ \\
Interpersonal Skills & $4.4 \%$ & $8 \%$ \\
Increase Confidence & $8.8 \%$ & $8.7 \%$ \\
Failure to Respond to Correction & $3.8 \%$ & $0 \%$ \\
Self Management & $3.7 \%$ & $6 \%$ \\
Speed & $2.2 \%$ & $1 \%$ \\
Take Initiative & $19.3 \%$ & $18.1 \%$ \\
Time Management and Organization & $7.4 \%$ & $6.7 \%$ \\
Writing and Communication & $18.5 \%$ & $24.1 \%$ \\
\hline Percent of Comments Referring to Criticisms & $11.3 \%$ & $9 \%$ \\
\hline
\end{tabular}


Table 7: Criticisms by Location

\begin{tabular}{cccccc}
\hline \hline & Nonprofit & Think Tank & International Govt & U.S. Govt & Business \\
\hline Attention to Detail & $15 \%$ & $14.3 \%$ & $6.1 \%$ & $10.4 \%$ & $23.9 \%$ \\
Deepen Knowledge & $9.4 \%$ & $21.4 \%$ & $17.6 \%$ & $11.2 \%$ & $8.6 \%$ \\
Engagement & $6.8 \%$ & $14.3 \%$ & $0 \%$ & $2.5 \%$ & $0 \%$ \\
Interpersonal Skills & $4 \%$ & $7.1 \%$ & $0 \%$ & $7.6 \%$ & $4.3 \%$ \\
Increase Confidence & $10.7 \%$ & $0 \%$ & $17.6 \%$ & $11.9 \%$ & $0 \%$ \\
Failure to Respond to Correction & $2.5 \%$ & $7.1 \%$ & $0 \%$ & $0 \%$ & $2.1 \%$ \\
Self Management & $2.5 \%$ & $0 \%$ & $0 \%$ & $6.8 \%$ & $8.6 \%$ \\
Speed & $2.5 \%$ & $0 \%$ & $5.9 \%$ & $0 \%$ & $2.1 \%$ \\
Take Initiative & $13.7 \%$ & $28.6 \%$ & $23.7 \%$ & $17.2 \%$ & $23.9 \%$ \\
Time Management and Organization & $10.9 \%$ & $3.6 \%$ & $0 \%$ & $9.4 \%$ & $8.7 \%$ \\
Writing and Communication & $25 \%$ & $3.6 \%$ & $29.1 \%$ & $23 \%$ & $17.8 \%$ \\
\hline Percent of Comments Referring to Criticisms & $10.5 \%$ & $10.8 \%$ & $9.1 \%$ & $9.3 \%$ & $9.2 \%$ \\
\hline
\end{tabular}

\section{A5. A Positive Note}

As evidenced in both Table 8 and Table 9, there is a consistent frequency in the positive comments across genders and location. Notably, the frequency of positive comments is double the frequency of negative comments, which support the high quantitative ratings.

Table 8: Positive Comments by Gender

\begin{tabular}{lcc}
\hline \hline & Females & Males \\
\hline Positive Comments & $21.4 \%$ & $21.5 \%$ \\
\hline
\end{tabular}

Table 9: Positive Comments by Location

Nonprofit Think Tank International Govt U.S. Gort Business

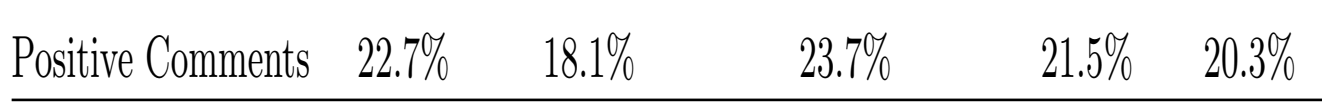




\title{
A7. Copy of Internship Evaluation Instrument
}

\author{
POLITICAL SCIENCE INTERNSHIP \\ PSC 2987 Internship Supervisor Evaluation
}

Please note: In order for the student to receive credit for his/her internship, this evaluation must be returned to me by Tuesday 1 May

Please mail, fax, or email the completed form.

Student Name:

Name of Organization:

Supervisor Name: :

Phone: (

Internship Start Date:

Internship End Date: , .

*Total Number of Hours Worked:

On a scale from 1 (poor) to 5 (excellent), please evaluate the student's performance during the intemship with respect to the following criteria:

1. Dependability
(Comments)

2. Work Ethic

(Comments)

3. Attendance / Punctuality

(Comments)

4. Usefulness to the Organization (Comments)
5. Works Effectively with Others

(Comments)

6. Quantity of Work Produced

(Commen!s)

7. Quality of Work Produced (Comunents)

8. Level of Initiative

(Comuntents) 
9. Please identify a specific project or situation for which the intern was responsible and comment on his/her performance

10. Please list any overall recommeridations for improvement in the student's performance.

1

11. From your perspective, was the student's internship a good learning experience for him/her? Yes: No___ (Why?)

12. Do you feel that it is appropriate for the student to earn academic credit based on his/her performance? Yes No___._(Why?)

13. Overall, was the student's performance satisfactory? Yes No _____ (If no, why not?)

14. Additional Comments or Observations:

15. Have you discussed this evaluation with your student? Yes No

(Do you want this evaluation to be confidential? Yes_._. No. J

16. Would you be interested in having another GW intern work for you? (Yes No___ 